УДК 792.73

DOI: 10.31866/2616-759x.2.2018.153223

Деркач Світлана Миколаївна, кандидат мистеитвознавства, професор, заслужений діяч мистецтв Украӥни,

Київський університет культури, Киів, Украӥна snderkatch@mail.com ORCID: https://orcid.org/0000-0002-5963-6463

Фімер Володимир Михайлович, заслужений діяч мистещтв Украӥни,

Киӥвський університет культури,

Київ, Украӥна vmfisher@ukr.net

ORCID: https://orcid.org/ 0000-0003-4045-7024

\title{
ВИЗНАЧАЛЬНІ ОЗНАКИ ЕСТРАДНОГО НОМЕРА ЯК СТРУКТУРНОЇ ОДИНИЦІ ЕСТРАДНОГО МИСТЕЦТВА
}

Мета дослідження полягає у формуванні визначальних ознак естрадного номера як структурної одиниці естрадного мистецтва, як окремого логічно й композиційно побудованого виступу одного або декількох виконавців, що поєднує в собі жанрові різновиди інших мистецтв, спільність яких полягає в тісному зближенні виконавців та публіки, у лаконічності, мобільності й розважальності. Методи дослідження. Етимологічний метод знадобився для визначення походження поняття «естрадне мистецтво»; компаративний метод дав змогу здійснити порівняльний аналіз ознак малих форм у мистецтві; семіотичним методом автори скористалися для аналізу відповідної термінології, а семантичним - для аналізу їхніх смислів; аналітикоконцептуальний метод дав підстави визначитися 3 поняттям естрадного номера як «молекули» естрадного мистецтва; завдяки системному методу здійснено систематизацію визначальних ознак естрадного номера. Наукова новизна дослідження полягає в тому, що вперше в мистецтвознавчій науці систематизуються визначальні ознаки естрадного номера як синтетичного мистецького явища, як самостійної структурної одиниці естрадного мистецтва, його специфіка, а, отже, відмінності від інших малих мистецьких форм. Разом з цим автори пропонують власне тлумачення дефініції «естрадний номер». Висновки. Естрадний номер є синтетичним мистецьким явищем, що становить собою «атом» естрадного мистецтва, його відносно самостійну структурну одиницю у вигляді логічно та композиційно побудованого виступу одного або кількох виконавців. Визначальними ознаками естрадного номера $\epsilon$ його синтетичність, короткометражність, концентрованість змісту, лаконічність, яскрава видовищність, динамічність, мобільність, актуальність, розважальність та безпосередній контакт виконавців з публікою.

Ключові слова: естрадне мистецтво; естрадний номер; естрадні жанри; «легкі» жанри. 
Постановка проблеми. Останнім часом доволі популярним є явище, означуване словом «естрада». Стосовно цього «легкого» жанру багато дискутують, висуваючи різні й часто зовсім полярні судження. Видаються історичні дослідження, збірки, присвячені творчості окремих артистів естради, мемуари діячів естради й ін. Однак вивчення такого виду мистецтва, як естрадне, сьогодні $є$ недостатнім у сфері науки. Недарма відомий композитор і виконавець Л. Утьосов стверджував: «Естрада - поняття, що важко піддається конкретному визначенню» (1961, с.149).

Мистецтвознавство надто обережно ставиться до визнання естради як виду мистецтва. Ситуація ускладнюється тим, що в світовому мистецтвознавстві не існує поняття «естрадне мистецтво». В різних країнах функціонують різноманітні розважальні форми під назвою «вар'єте», «шоу», «мюзик-хол», «кабаре», «кафе-концерт» тощо, однак естрадне мистецтво, як суверенний вид мистецтва, не знайшов своєї постійної прописки на шпальтах наукових видань.

Оскільки теоретичні основи естради ще недостатньо розроблені, професійна термінологія у цій сфері вельми умовна. Використовуючи в повсякденній мові поняття «естрадне мистецтво», ми не завжди виокремлюємо його в самостійний вид мистецтва, інколи тлумачачи естраду як засіб поєднання творів різних видів мистецтв. Проте можна помітити, що пісня, танець, пантоміма, ілюзіон, драматична сценка чи монолог, винесені на естрадний майданчик, набувають певних загальних ознак, які надають естраді статусу «суверенного» виду мистецтва. Виявивши ці ознаки, назвавши їхні складники та визначивши їхні кордони, можна зрозуміти специфіку самого поняття «естрадний номер» і простежити можливість існування поняття «естрадне мистецтво» в науковій площині.

Аналіз останніх досліджень і публікацій. Наукових досліджень із заявленої теми майже не існує. Однак варто нагадати, що поняття «естрада» походить від латинського stratum та означає «підвищення у концертному залі, передбачене для виступу артистів. На відміну від сцени, не має передньої та задньої завіс, куліс, театральних машин» (Дмитриев, 1967, с.1026). Водночас в Українській радянській енциклопедії поняття «естрадне мистецтво» тлумачиться як «вид мистецтва, що об'єднує деякі музичні (пісня, інструментальна п’єса), хореографічні (танець, мініатюра), театральні (інтермедія, скетч, фейлетон), циркові (жонглювання, еквілібристика, акробатика, дресирування) жанри» (1979, с.60). Однак це визначення, на нашу думку, є не зовсім повним. Адже естрада «розмовляє» мовами майже всіх видів мистецтв, поєднуючи в собі літературу, театр, музику, танець, цирк, кінематограф тощо. Різноманітними $є$ також і жанри естради, в яких наявні всі види виконавської творчості, класифіковані за темами (від глобальних - до суто місцевих), за сценічними майданчиками (від столичних Палаців культури - до парків і вулиць), за авторами (від класиків - до власних творів) тощо. Естрада немов би «розсипається» на окремі чинні у своїх законах форми художньої творчості. Театральна енциклопедія називає естраду (мистецтво естради) «мистецтвом малих форм» (1967, с.1023). Саме у форматі малих форм і полягає одна з визначальних ознак естрадного мистецтва. Однак мала форма широко використовується і в так званих філармонійних жанрах, що здебільшого принципово відрізняються від естради. Більше того, в усіх видах мистецтв «мала форма» існує поряд з «великою». На естраді їхня рівноправність відсутня, а відносини між ними мають специфічний характер. 
Структурною одиницею мистецтва естради $\epsilon$ естрадний номер виокремлений, логічно та композиційно вибудуваний виступ одного або кількох виконавців. Сукупність естрадних номерів, організованих за законами естрадної драматургії, є естрадним видовищем. Останнє може бути естрадним концертом, естрадною виставою, естрадним оглядом (ревю, шоу, тощо). Саме номер, як мала естрадна форма, як «атом» естрадного мистецтва, формує структуру всієї естрадної вистави, естрадного видовища чи концерту (великих форм), що складаються з естрадних номерів різних жанрів.

То в чому ж полягає відмінність естрадного номера від малих форм 3 тими ж якостями, що існують в інших видах мистецтв? Оскільки номер - структурна одиниця естрадного мистецтва, потрібно визначити специфіку естрадного номера, що відрізняє його від філармонійних та інших видів.

Однією $з$ ознак естрадного твору $є$ безпосереднє зближення виконавців 3 публікою, що створює особливу систему спілкування між ними. Виконавець під час виступу перетворює глядачів-слухачів на активних партнерів, провокує ïx на реакцію та залучає до активної дії, займаючи відносно публіки позицію максимальної довіреності, відкритості та відвертості. Однак система епічного театру Б. Брехта також припускає пряме звернення артиста до глядача, який немовби стає безпосереднім учасником дії. На початку 20-х років XX ст. 3 цією ж метою проводив експерименти із «підсадними» акторами серед публіки й В. Мейєрхольд. Навряд чи варто відносити на заслугу естради знищення «четвертої стіни», хоча ця концепція є досить спокусливою, іiі дотримуються багато дослідників, які заперечують тим самим походження естради від театрального мистецтва. Театр, як і естрада, своїми далекими предками вважає давньоруських скоморохів, французьких гістріонів, німецьких шпільманів, середньоазіатських масхарабазів тощо, мистецтво яких будувалося на безпосередньому зверненні до глядача. На відкритому контакті 3 публікою будувалося мистецтво й італійської комедії дель-арте. Про прямий контакт iз глядацьким залом пишуть і дослідники зарубіжного театру: «Актор, а часто він і автор, що виконував головну роль, жваво спілкувався 3 аудиторією, яка бурхливо реагувала на запропоновані комедії, була якоюсь мірою співучасником вистави i навіть немовби непрямим співавтором п’єси» (Сидорин, 1985, с.10).

Як бачимо, безпосереднє спілкування з публікою, тією чи іншою мірою, було завжди в театральному мистецтві. Естрада, звертаючись до історичних витоків, підхопила та розвинула цей прийом.

Ще однією ознакою естради, а звідси й естрадного номера, є лаконічність та мобільність всіх виразних засобів. Естрадний номер не може бути розтягнутим у часі (зазвичай його тривалість не довша 5-10 хвилин). Тому естрадний номер - це передусім чіткий сюжет, добре продумана композиція, гостра кульмінація, виразна авторська позиція, влучні акценти та ефектний фінал. Тут не існує заглиблених психологічних характеристик героїв, розгорнутих фабульних ходів, багатьох дійових осіб. Я.М. Зіксінд у мемуарній публікації цитує тезу відомого артиста радянської циркової клоунади М. М. Румянцева: «Основний закон драматургії: ефектний початок, цікава середина, яскравий фінал. <..> У творах для цирку та естради має бути початок, що інтригує, змістовна та логічно точна середина та неочікуваний 
фінал. I чудово, якщо цей фінал нестандартний, не повторює існуючі, неодноразово виконувані...» (1976, с.21).

Ще одна ознака естрадного номера - актуальність, максимальна наближеність до сьогодення. Видатний майстер естради А. Райкін зазначав: «Естрада - мистецтво гостросучасне. Воно повинно відображати сьогоднішній день чи навіть завтрашній, але ніяк не вчорашній. Те, що було сьогодні в газеті, естрадному артисту брати вже пізно. Треба відчути час, зрозуміти, про що думають люди, що вони хочуть побачити та почути» (Сидорин, 1985, с.272).

Загальноприйняті види мистецтва (театр, музика тощо) уводять глядачаслухача у свій світ, а естрадний номер «сам приходить до глядача, залишаючи його на місці (в залі та в житті), у сьогоднішньому дні, але емоційно змальовуючи те, що ми бачимо в дійсності, виражає це в своїй, лише естраді властиві формі» (Германова, 1986, с.14).

Видається, що будь-яка ознака, що визначає естрадний номер зокрема, як і естрадне мистецтво взагалі, $є$ неоднозначною. Кожне на перший погляд справедливе твердження можна легко спростувати. Тому «...жах професії людини, яка виходить на естраду і дозволяє собі вголос говорити власні слова й думки, в тому, - писав Смирнов-Сокольський, - що в ній розуміються абсолютно всі» (1976, с.40). I справді, будь-яка далека від мистецтва людина має своє уявлення про естраду.

Різноманітні форми художньої творчості, які вбирає в себе поняття «естрада», сприймаються насамперед як розважальні, орієнтовані на проведення дозвілля. Розважальність, як і ряд інших ознак, обумовлених генеалогію цього мистецтва, відрізняє сучасний естрадний номер від інших мистецтв. Естраду називають легким жанром, не беручи до уваги, що ця легкість може бути оманливою. Існує безліч естрадних номерів, у яких легкість створюється майстрами за допомогою складних для виконання прийомів. Наприклад, театралізований джаз-оркестр Леоніда Утьосова, структурований та композиційно вибудований за законами театральної вистави; ілюзіон Давида Копперфільда, побудований на суперскладній інженерній технології та акторському хисті ілюзіоніста; жонгляж німецького майстра розмовного жанру Лотара Льора, який під час жонгляжу коментував свої трюки; мистецтво українського артиста розмовного жанру Георгія Павленка, який з'єднував гру на тромбоні 3 виконанням гостросоціального фейлетону; мистецтво Майкла Джексона, побудоване на віртуозному синтезі музики, пластики, хореографії, сценографії та режисури; урешті-решт, мистецтво ранньої гіперхаризматичної Алли Пугачової, яка створила «вокальний театр однієї співачки» («Арлекін», «Все можуть королі» й ін.). Перелік цей можна продовжувати й продовжувати.

Момент розважальності, притаманний естрадному мистецтву взагалі, а естрадному номеру зокрема, має й інший, психологічний аспект. Психологи розглядають сміх як засіб спілкування людей та їхню релаксацію. Висміювання недоліків, поширених негативних явищ дарує людям почуття незалежності й самоствердження. Отже, розважальність - наступна ознака естрадного номера, що надає йому легкості, святковості, оригінальності та різноманітності.

Розглянувши й дослідивши головні, на нашу думку, ознаки, що відрізняють естраду, а, отже, іiі «атом»- естрадний номер, з-поміж інших видів мистецтв, можна стверджувати, що останньому притаманне безпосереднє зближення 
виконавців із публікою, лаконічність та мобільність усіх виразних засобів, актуальність пропонованого матеріалу та розважальність.

Звичайно, можна спростувати думку про те, що всі вищенаведені ознаки належать виключно естрадному номеру, адже багато драматичних вистав $\epsilon$ також розважальними та злободенними, і зберігають при цьому природу театрального мистецтва. Лаконічність та мобільність існує в хореографічному та музичному мистецтвах. Що стосується розважальності, то вона значною мірою зустрічається у всіх видах мистецтва.

Висновки. Естрадний номер $\epsilon$ синтетичним мистецьким явищем, що становить собою «атом» естрадного мистецтва, його самостійну структурну одиницю у вигляді логічно та композиційно побудованого виступу одного або декількох виконавців. Визначальними ознаками естрадного номера $\epsilon$ його синтетичність, короткометражність, концентрованість змісту, лаконічність, яскрава видовищність, динамічність, мобільність, актуальність, розважальність та безпосередній контакт виконавців із публікою.

\section{Список посилань}

Германова, М.Г., 1986. Эстрадный номер: (Разговорные жанры эстрады). Москва: Советская Россия.

Дмитриев, Ю.А, 1967. Эстрада. В: Марков, М.П. ред. Театральная энииклопедия, Т.5. Москва: Советская энциклопедия, с.1023-1026.

Естрада, 1979. В: Бажан М.П. ред. Українська радянська енциклопедія, в 12 т. Т.4. Київ: Головна редакція Української радянської енциклопедії, с.60.

Зиксид, Я., 1983. Секреты жанра. Советская эстрада и цирк, 9, с.20-21.

Сидорин, Г., 1985. Венская народная комедия ХІХ века. Москва: Искусство.

Смирнов-Сокольский, Н., 1976. Сорок пять лет на эстраде. Москва: Искусство.

Уварова, Е.Д. ред., 1988. Эстрада. Что? Где? Зачем?. Москва: Искусство.

Утесов, Л., 1961. С песней по жизни. Москва: Искусство.

\section{References}

Germanova, M.G., 1986. Estradnyiy nomer: (Razgovornyie zhanryi estradyi) [Pop Number: (Conversation Pops)]. Moscow: Sovetskaya Rossiya.

Dmitriev, Ju.A, 1967. Estrada. In: Markov, M.P. ed., Teatralnaya entsiklopediya [Theater Encyclopedia]. T.5 Moscow: Sovetskaya entsiklopediya.

Estrada, 1979. In: Bazhan M.P. ed., Ukrainska radianska entsyklopediia [Ukrainian Soviet Encyclopedia], Vol.1-12, Vol.4. Kyiv: Holovna redaktsiia Ukrainskoi radianskoi entsyklopedii Ziksid, Ya., 1983. Sekretyi zhanra [Secrets of the genre]. Sovetskaya estrada i tsirk, 9, pp.20-21.

Sidorin, G., 1985. Venskaya narodnaya komediya XIX veka [Viennese folk comedy of the nineteenth century]. Moscow: Iskusstvo.

Smirnov-Sokolskiy, N., 1976. Sorok pyat let na estrade [Forty-five years on the stage]. Moscow: Iskusstvo.

Uvarova, E.D. ed., 1988. Estrada. Chto? Gde? Zachem? [Stage. What? Where? What for?]. Moscow: Iskusstvo.

Utesov, L., 1961. S pesney po zhizni [With a song in life]. Moscow: Iskusstvo.

\footnotetext{
(C) Деркач C.M., 2018

(C) Фішер B.M., 2018
} 
Derkach Svitlana, PhD in History of Arts, Professor, Honored art worker in Ukraine, Kyiv University of Culture, Kyiv, Ukraine

Fisher Volodymyr, Honored art worker in Ukraine, Kyiv University of Culture,

Kyiv, Ukraine

\section{THE EXTRAORDINARY RANGE DETAILS AS STRUCTURAL UNIT IN ESTABLISHMENT ART}

The purpose of the article is to form the main features of the variety number as a structural unit of pop art, as a separate logically and compositionally constructed performance of one or more performers, combining genre types of other arts whose commonality lies in the close rapprochement of performers and the public, in concordance, mobility and entertainment. Research methods. The etymological method has been used to determine the concept of "variety art» origin; The comparative method allowed the comparative analysis of the small forms signs in art; The semiotic method has been used by the authors for the analysis in the corresponding terminology, and semantic has been used for the analysis of their meanings; the analytical-conceptual method allowed the authors to define the concept of variety number as a «molecule» in pop art, and the systematic method has been used by the authors to systematize the key features in the variety number. The novelty of the study is that for the first time, in the science of art studies the main features of the variety number as a synthetic artistic phenomenon have been systematized as an independent structural unit in pop art, its specifics, and, consequently, differences from other small artistic forms. However, the authors offer their own interpretation in the definition of «pop number». Conclusions. Variety number is a synthetic artistic phenomenon, representing the «atom» of pop art, its relatively independent structural unit in the form of a logical and compositionally constructed performance of one or more performers. The key features of the variety number are its synthetic, short, content, concise, vivid entertainment, dynamism, mobility, relevance, entertainment and direct contact of performers with the public.

Key words: variety art; pop number; pop genres; «light» genres. 
Деркач Светлана Николаевна, кандидат искусствоведения, профессор, заслуженный деятель искусств Украины,

Киевский университет культуры, Киев, Украина

Фишер Владимир Михайлович, заслуженньй деятель искусств Украины, Киевский университет культурь, Киев, Украина

\section{ОПРЕДЕЛЯЮЩИЕ ПРИЗНАКИ ЭСТРАДНОГО НОМЕРА КАК СТРУКТУРНОЙ ЕДИНИЦЫ ЭСТРАДНОГО ИСКУССТВА}

Цель исследования заключается в формировании определяющих признаков эстрадного номера как структурной единицы эстрадного искусства, как отдельного логично и композиционно построенного выступления одного или нескольких исполнителей, сочетающего в себе жанровые разновидности других искусств, общность которых заключается в тесном сближении исполнителей и публики, в лаконичности, мобильности и развлекательности. Методы исследования. Этимологический метод понадобился для определения происхождения понятия «эстрадное искусство»; компаративный метод позволил осуществить сравнительный анализ признаков малых форм в искусстве; семиотическим методом авторы воспользовались для анализа соответствующей терминологии, а семантическим - для анализа их смыслов; аналитико-концептуальный метод позволил авторам определиться с понятием эстрадного номера как «молекулы» эстрадного искусства; системным методом совершено систематизацию определяющих признаков эстрадного номера. Научная новизна исследования заключается в том, что впервые в искусствоведческой науке систематизируются определяющие признаки эстрадного номера как синтетического художественного явления, как самостоятельной структурной единицы эстрадного искусства, его специфика, а, следовательно, отличия от других малых художественных форм. Вместе с тем авторы предлагают собственную трактовку дефиниции «эстрадный номер». Выводы. Эстрадный номер является синтетическим художественным явлением, которое представляет собой «атом» эстрадного искусства, его относительно самостоятельную структурную единицу в виде логически и композиционно построенного номера одного или нескольких исполнителей. Отличительными особенностями эстрадного номера является его синтетичность, короткометражность, концентрированность содержания, лаконичность, яркая зрелищность, динамичность, мобильность, актуальность, развлекательность и непосредственный контакт исполнителей с публикой.

Ключевые слова: эстрадное искусство; эстрадный номер; эстрадные жанры; «легкие» жанры. 